\title{
The usage of live invertebrates at the expositions of the Museum of Natural Science
}

\author{
Ekaterina Pyatina ${ }^{1}$, Marina Bulgakova ${ }^{2, *}$ \\ ${ }^{1}$ V.V. Dokuchaev Soil Science Institute, 119017, Moscow, Pyzhevsky lane 7, Russia \\ ${ }^{2}$ Orenburg State University, 460018, Orenburg, Pobedy st. 13, Russia
}

\begin{abstract}
The usage of live invertebrates at excursions have been considered by us in order to attract interest for multifunctional and multicomponential system - soil.
\end{abstract}

The Central Museum of Soil named after V. V Dokuchaev was founded in 1904. The main object to be exposed in the museum is soil which in most cases is demonstrated in shape of soil monoliths having been selected and transported in different parts of our planet $[1,2]$. The monolith represents a vertical slice of soil in an undisturbed form of prism. Soil is one of the most complicated natural objects to be demonstrated at any exposition of Natural Science.

Firstly, a human being always takes it for an object and some industrial material - it's a rather utilitarian approach to all the significance of soil.

Secondly, as a museum exhibit, soil possesses little attraction for a visitor due to its modest external expressivity, more over, separated from the environment, soil becomes "understandable" only to the soil specialists.

Some maps, photos, drawings, models, schedules, paintings, sculptures, patterns of biological material and many other things are used to attract the visitor's attention just to the soil monoliths as the main exhibits.

A long educational work has been conducted to make the younger generation environmental friendly along with wide spreading the information about soil since the very foundation of the Museum [1-5]. Only some soil specialists had known about The Dokuchaev Museum of Soil before school children of different age started visiting it in the new century. In order to attract them, some interactive excursions are worked out and conducted. And also game excursions with route brochures, quests, lab study and master classes. They've started to use the live exhibits for the excursion work of the Museum quite recently [6].

"The live Conor" draws special attention of visitors regardless of their age. Live exhibits are very popular among children and they play a very significant role in cultivating their emotional attitude towards the live Nature. They help kids and young school children to form their efficient Nature images and their environmental culture.

With a help of live exhibits, we can better explain all the peculiarities of soil as natural habitat. We can also show that inside the soil which is a bio inert matter of the biosphere,

\footnotetext{
*Corresponding author: biosu@mail.ru
} 
the live matter converting the soil itself into some other substance, plays a very important role. One can find representatives of all the species of live Nature. As for the number of bacterias, the soil as a habitat, exceeds all the other habitats on our planet.

On the Night of Museums live invertebrates were used for the first time. The visitors sitting by the diorama "Steppe", having closed their eyes, were listening to the chirping of the crickets and they momentarily found themselves transferred from nocturnal Saint Petersburg to the steppe. Since then, the crickets (Gryllus locorojo) have become constant participants of excursion programs designated for various actions, and were "interwoven" into many constant excursions of the Museum as well.

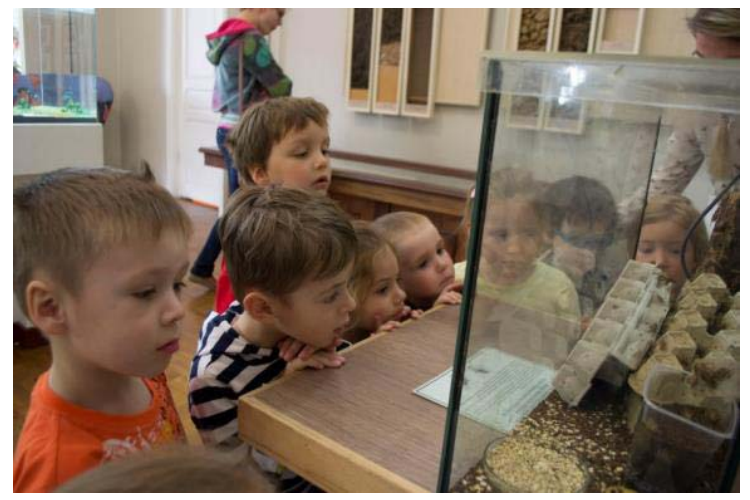

Fig. 1. Crickets (Gryllus locorojo).

In 2011, the Museum represented the exposition "Incubator of life" at the exhibition "Life. The version of science". It took place in Moscow where the visitors could "overlook" activity of annelid worms, watching one of the stages of closing the biological circulation on dry land (a video installation, an object with live organisms "Enchitreidas" Enchytraeidae which from time to time participate in different programs of the Museum. For example on the Night of the Museums in 2016.

In 2012 the laboratory class "Underground inhabitants under microscope" was worked out for the exhibition of popular-scientific exhibits "The Scientific Museum in the 21 century" which took place in The Museum of Industrial history belonging to the City of Petrozavodsk in 2012.

During the class the visitors were making some temporal micro preparations and they were watching the microscopic soil organisms such as the infusoria - Paramecium caudstum, the amoeba - Amoeba proteus, the rotifers - Rotatoria, nematodes - Nematoda.
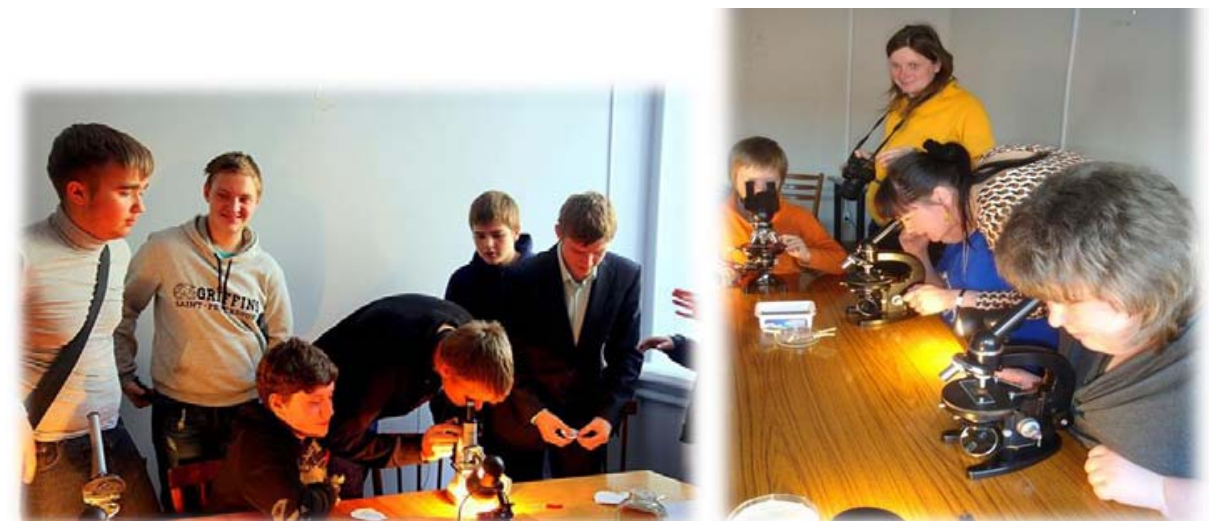

Fig. 2. A laboratory class called "Underground inhabitants under microscope" 
Another live exhibit, the family of the garden black ant has settled behind the walls of the Museum - Lasius niger. A special excursion has been worked out for this purpose "One, two-I'm turning into an ant". Which has taken place in the parallel program of The Childish Days in Saint Petersburg for the first time. One could watch live ants and see their home with a help of a magnifying glass and observe the ants through a microscope during the travelling game. The game participants learn about different kinds of ants, about the life of the anthill, get familiar with their enemies and friends, about the role which ants play in the environment and their influence on the soil. Whether a human being is so different from ants and what people can learn from them. You may find the answer to this question during the game, trying on a part of a princess, a soldier, a spy, a nurse or a working ant. A board environmental game showing all the significance of "the little workers" for the Nature is awaiting children as the final part of the activity.

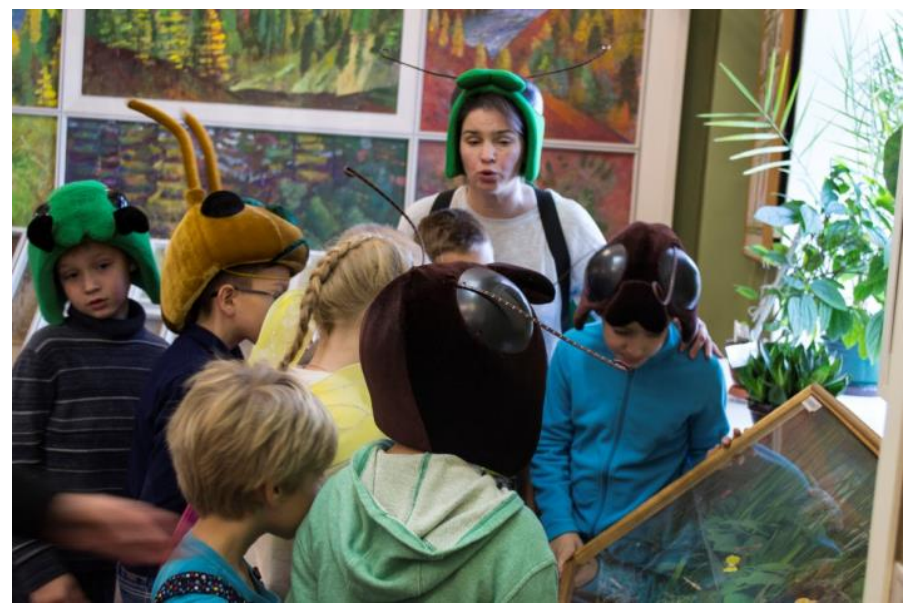

Fig.3. Excursion "One, two - I'm turning into an ant!"

The Achatina snails - Achatina reticulata and the beetles - Zophobas motio have become an integral part of the exposition this year. A special program was developed "The very first plowman" for The night of the museums in 2016. From this program the visitors can learn that the very first plowman is the rain worm and the largest earth worms are Australian (up to $3 \mathrm{~m}$ long), that the soil with much gratitude accepts the vermicompost "tea" and many other things. The vermiculture of the manure worm has been cultivated for this program Eisenia fetida.

An interactive costume class "Wonderful transformation if insects" had been worked out for the Night of the Museums by 2018. At this class children found out what it would be like to be a butterfly. During the command game the participants learnt about the life of soil inhabitants, got to know the peculiarities of the insects' development with complete and incomplete transformation. Some new inhabitants of "the live corner" - The Olive kivsyak Telodeinopus aoutii and wood lice - Porcellio scaber appeared in the museum in 2019. 


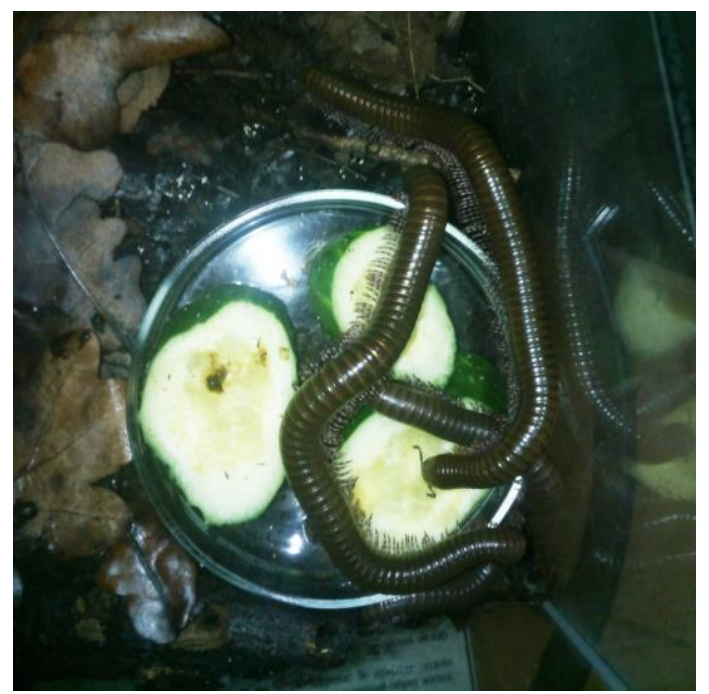

Fig. 4. The Olive kivsyak (Telodeinopus aoutii).

They serve as a good pattern for those who research the invertebrates, they are the indicators of the condition the soil is in. A scientific game program "Calsium-a miraculous element!" had been worked out by The Night of the Museums in 2019. It was designed for the senior children of preschool age and for young school children. The program helps to form some positive motivation for healthy life style, being careful for the environment and getting new knowledge.

The guys visited a mini laboratory, put a chemical test by themselves, watched the life of the animals-indicators and observed them under microscope while fulfilling the task together with "the centipede".

Different forms of work with visitors, creating of live expositions, cooperation with environmental organizations and institutions promote formation of ecological worldview and increase the number of visitors, breaking all the stereotypes about The Museum of Natural Science.

\section{References}

1. B. F. Aprain, R. P. Dedenina, Guidelines for Creating Soil Expositions and Exhibitions (Leningrad, 1984)

2. B. F. Aparin, Dokuchaev's Paradigm of Natural Science (TRIZ-Profi, Moscow, 2006) [in Russian].

3. Ye. A. Rusakova, Materials on the study of Russian soils, 8(35), 61-65 (2014).

4. Ye. Yu. Sukhacheva, B.F. Aparin, Biosfera, 3, 146 (2019)

5. B. F. Aparin, E.Y. Sukhacheva, Soil Sciences Education: Global Concepts and Teaching, 10, 103 (2020)

6. E. V. Pyatina, M. A. Bulgakova, Concep. and appl. asp. of res. in the field of inverteb. zoo. (2020) 